\title{
Amelioration of Binge Eating by Nucleus Accumbens Shell Deep Brain Stimulation in Mice Involves D2 Receptor Modulation
}

\author{
Casey H. Halpern, ${ }^{1}$ Anand Tekriwal, ${ }^{2}$ Jessica Santollo, ${ }^{3}$ Jeffrey G. Keating, ${ }^{4}$ John A. Wolf,,${ }^{1}$ Derek Daniels, ${ }^{3}$ \\ and Tracy L. Bale ${ }^{2}$ \\ Departments of ${ }^{1}$ Neurosurgery, ${ }^{4}$ Neurology, and ${ }^{2}$ Animal Biology, University of Pennsylvania, Philadelphia, Pennsylvania 19104, and ${ }^{3}$ Department of \\ Psychology, University at Buffalo, State University of New York, Buffalo, New York 14260
}

Hedonic overconsumption contributing to obesity involves altered activation within the mesolimbic dopamine system. Dysregulation of dopamine signaling in the nucleus accumbens shell (NAS) has been implicated in reward-seeking behaviors, such as binge eating, which contributes to treatment resistance in obesity (Wise, 2012). Direct modulation of the NAS with deep brain stimulation (DBS), a surgical procedure currently under investigation in humans for the treatment of major depression, obsessive-compulsive disorder, and addiction, may also be effective in ameliorating binge eating. Therefore, we examined the ability of DBS of the NAS to block this behavior in mice. c-Fos immunoreactivity was assessed as a marker of DBS-mediated neuronal activation. NAS DBS was found to reduce binge eating and increased c-Fos levels in this region. DBS of the dorsal striatum had no influence on this behavior, demonstrating anatomical specificity for this effect. The dopamine D2 receptor antagonist, raclopride, attenuated the action of DBS, whereas the D1 receptor antagonist, SCH-23390, was ineffective, suggesting that dopamine signaling involving D2 receptors underlies the effect of NAS DBS. To determine the potential translational relevance to the obese state, chronic NAS DBS was also examined in diet-induced obese mice and was found to acutely reduce caloric intake and induce weight loss. Together, these findings support the involvement of the mesolimbic dopamine pathways in the hedonic mechanisms contributing to obesity, and the efficacy of NAS DBS to modulate this system.

\section{Introduction}

The rising prevalence of obesity is a worldwide concern given increased risk for diabetes and metabolic syndrome (Jeffery et al., 2004; Li et al., 2005; Sturm, 2007; Finucane et al., 2011). Binge eating affects $\sim 30 \%$ of obese individuals, contributing to this condition's treatment resistance (Hsu et al., 1997; Gorin et al., 2008). This propensity for uncontrolled eating is related to hedonic properties of highly palatable, calorically dense food (Nair et al., 2009), mediated by the mesolimbic dopamine system's projections from the ventral tegmental area to the nucleus accumbens (NA) (Wise and Rompre, 1989; Teegarden and Bale, 2007; Stoeckel et al., 2008; Teegarden et al., 2008). This circuitry has been previously described to underlie addiction, suggesting common neural pathways (Nestler, 2005). Obesity, like addiction, has been associated with decreased dopamine type 2 receptor (D2R)

Received July 7, 2012; revised Feb. 6, 2013; accepted Feb. 28, 2013.

Author contributions: C.H.H., A.T., J.G.K., J.A.W., D.D., and T.L.B. designed research; C.H.H., A.T., J.S., and D.D. performed research; C.H.H., A.T., J.G.K., J.A.W., and T.L.B. analyzed data; C.H.H., A.T., J.S., J.G.K., J.A.W., D.D., and T.L.B. wrote the paper.

This work was supported in part by National Institutes of Health Grant T32DA022605- 05 to C.H.H. and Grant HL091911 to D.D. We thank C. Taylor, J. Fluharty, C. Siegel, M. Attiah, C. Morgan, A. Roland, W. Rodemer, H. Juul, and A. Cohen for technical assistance; C. Howerton for support of the statistical analyses; and T. Wadden, M. Dichter, M. S. Grady, G. Baltuch, and J. Jaggi for scientific discussions.

The authors declare no competing financial interests.

Correspondence should be addressed to Dr. Tracy L. Bale, 201E Vet, 6046, 3800 Spruce Street, University of Pennsylvania, Philadelphia, PA 19104-6046. E-mail: tbale@vet.upenn.edu.

DOI:10.1523/JNEUROSCI.3237-12.2013

Copyright $@ 2013$ the authors $\quad 0270-6474 / 13 / 337122-08 \$ 15.00 / 0$ availability in portions of the striatum, including the NA, which may predispose to compulsive-like binge-eating behavior (Wang et al., 2001; Stice et al., 2008; Volkow et al., 2008; Johnson and Kenny, 2010). It is unclear whether such changes in the D2R are a consequence or cause of chronic exposure to a reward, such as a high-fat diet (Stice et al., 2011).

Deep brain stimulation (DBS) of the NA is currently under investigation as a therapy for major depression, obsessive-compulsive disorder, and substance abuse (Okun et al., 2007; Schlaepfer et al., 2008; Muller et al., 2009). DBS of the subthalamic nucleus and thalamus has already been established as an effective treatment for Parkinson's disease and essential tremor, respectively (Halpern et al., 2007; Toft et al., 2011). Given that multiple studies have implicated the shell subregion of the NA (NAS) in mediating reward sensation associated with food-seeking behavior, the present study examined whether targeting the NAS with DBS would modulate the hedonic mechanisms contributing to obesity in mice (Tanda and Di Chiara, 1998; Georgescu et al., 2005; Lamont et al., 2012). NAS DBS in rodent models has been found to mitigate other reward-seeking behaviors, such as cocaine reinstatement, and small pilot studies and case reports in humans suffering from addiction have reported decreased craving and high rates of abstinence (Vassoler et al., 2008; Muller et al., 2009; Valencia-Alfonso et al., 2012). One potential mechanism by which DBS may ameliorate such behavior is by modulating dopamine receptor-expressing neurons expressed in this brain region (Shi and Rayport, 1994; Sesia et al., 2010). 
Elucidation of the neuroanatomic, biochemical, and molecular bases of binge eating may facilitate the development of novel therapeutics for obesity. The present study examined the ability of NAS DBS to attenuate this behavior in mice. To determine whether DBS was functioning to effectively activate or inhibit neurons in the NAS, c-Fos immunoreactivity (c-Fos-IR) was measured. Involvement of the dopamine D1 receptor (D1R) and D2R in DBS function was examined by pretreatment with the receptor specific antagonists, $\mathrm{SCH}-23390(0.075 \mathrm{mg} / \mathrm{kg})$ and raclopride $(3 \mathrm{mg} / \mathrm{kg})$, respectively. Last, to examine the ability of NAS DBS to attenuate consumption in the obese state, chronic DBS was administered to diet-induced obese mice.

\section{Materials and Methods}

Animals. All mice were male C57BL/6J ( $N=73,8$ weeks) purchased from The Jackson Laboratory. Mice were individually housed on a $12 \mathrm{~h}$ light/ dark schedule with food and water ad libitum unless otherwise noted. House chow contained $28 \%$ protein, $60 \%$ carbohydrates, and $12 \%$ fat by calories and $4.00 \mathrm{kcal} / \mathrm{g}$ (Purina Lab Diet). Given a previously documented macronutrient preference for fat (Teegarden and Bale, 2007), a high-fat diet, which contained $20 \%$ protein, $20 \%$ carbohydrates, and $60 \%$ fat by calories and $5.24 \mathrm{kcal} / \mathrm{g}$ (Research Diets), was used in this study to model binge eating and diet-induced obesity. All studies were done according to the standards and guidelines of the University Laboratory Animal Resources and were approved by the Institutional Animal Care and Use Committee of the University of Pennsylvania.

Surgery. After 1 week of habituation to our facility, mice were anesthetized with isoflurane inhalation (5\% induction, $2 \%$ maintenance) and mounted in a stereotaxic frame (Kopf Instruments). A custom bipolar tungsten electrode (FHC) was implanted unilaterally into the left NAS, according to the following coordinates relative to bregma: $1.34 \mathrm{~mm}$ anterior, $0.60 \mathrm{~mm}$ lateral, and $4.25 \mathrm{~mm}$ deep to brain surface. The dorsal striatum was also targeted with DBS in a separate cohort of mice, according to the following coordinates relative to bregma: $1.34 \mathrm{~mm}$ anterior, $1.50 \mathrm{~mm}$ lateral, and $2.20 \mathrm{~mm}$ deep to brain surface. Mechanical etching using a high-speed hand drill was used to increase the surface area of the mouse skull, to which cyanoacrylate glue was applied (Agterberg et al., 2010). This procedure provided a bonding surface for the dental acrylic, which fastened the base of the electrode to the skull.

Binge eating. Body weight matched mice were randomly assigned to surgical and nonsurgical groups. Binge eating, defined here as consumption of $>25 \%$ of a mouse's daily caloric intake within a $1 \mathrm{~h}$ period, was observed in all mice using a limited access protocol. This protocol is known to induce binge-like behavior in noncalorically restricted mice because of the brevity and intermittent nature of the exposure (Pankevich et al., 2010). A single, preweighed high-fat pellet was provided to the mice in their home cage daily for $1 \mathrm{~h}$ (12:00 P.M. to 1:00 P.M.). Intake of the high-fat diet within that $1 \mathrm{~h}$ period was measured, as was $24 \mathrm{~h}$ consumption of house chow. This protocol continued until a stable level of high-fat intake was obtained (defined as $<15 \%$ variation in consumption over 3 consecutive days), at which point DBS was administered. In a separate cohort of mice, intake of a standard chow pellet in the binge paradigm was examined to ensure that binge eating was specific to the palatable high-fat food.

Acute DBS. All mice were allowed to recover for 1-week after surgery. For the purpose of habituation, mice implanted with DBS electrodes in the NAS $(N=12)$ or dorsal striatum $(N=11)$ were connected to external wires $3 \mathrm{~h}$ before starting the limited access protocol each day (Fig. 1A). Nonsurgical, weight-matched controls were handled in a similar manner $(N=7)$. A voltage-based stimulator with a built-in isolation circuit (SD9 Square Pulse Stimulator, Grass Technologies) was used to generate a continuous train of monophasic pulses $(60 \mu \mathrm{s}, 160 \mathrm{~Hz})$, with the baseline adjusted to achieve overall charge balance. The output of the stimulus isolator was monitored using an isolated probe (CT3684, Cal Test) and a factory-calibrated oscilloscope (TPS2000B, Tektronix). The administered current output from this constant voltage stimulator was calculated to be $150 \mu \mathrm{A}$, which remained stable from initiation to the end of each session. DBS was administered on 2 alternate days, to ensure that caloric

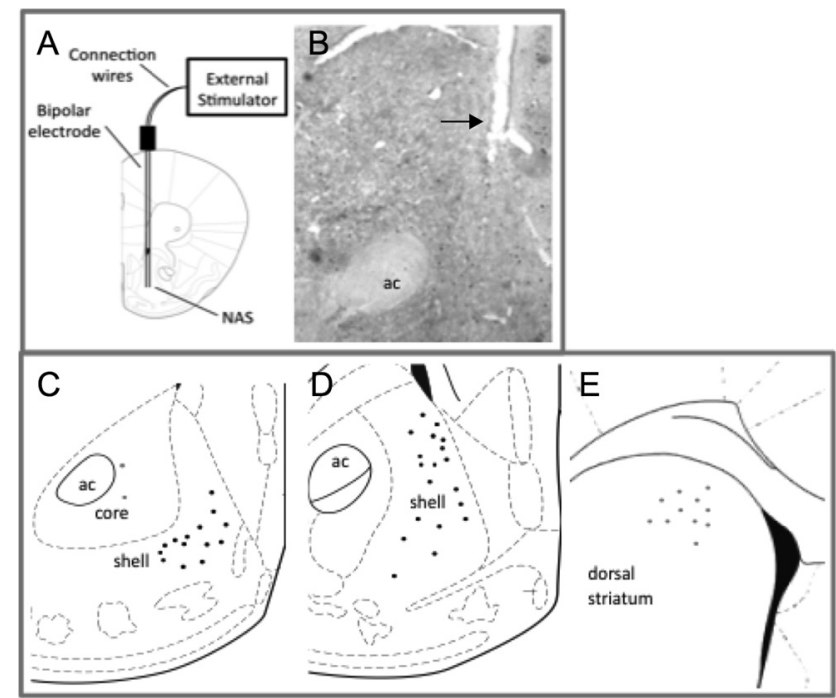

Figure 1. DBS electrode placement. $\boldsymbol{A}$, Schematic illustration of the setup for NAS DBS. $\boldsymbol{B}$, End of representative electrode tract in the NAS, indicated by black arrow. C-E, Electrode placements in the NAS ( $N=37$; filled black circles), core ( $N=2$; filled gray circles), and dorsal striatum ( $N=11$; filled gray circles). ac, Anterior commissure.

intake from high-fat food returned to baseline in between treatments. The stimulator was turned on immediately before access to the high-fat pellet and turned off after this $1 \mathrm{~h}$ period. Mice were then disconnected from external wires. On non-DBS days, mice were attached to the wires, but the stimulator was not turned on. The selection of parameters (pulse width, frequency, current intensity) was based on recent basic science and clinical work where current intensities are varied across studies (Benazzouz and Hallett, 2000; Chang et al., 2003; Mayberg et al., 2005; Vassoler et al., 2008; Bewernick et al., 2012). Thus, the influence of NAS DBS on binge eating was examined at $150 \mu \mathrm{A}$, an intensity previously found to be required to attenuate cocaine priming-induced reinstatement of drug seeking in rats, and $75 \mu \mathrm{A}$, or half of this intensity $(N=11)$ (Vassoler et al., 2008).

Video monitoring of activity. Video recording was performed during limited access to the high-fat diet to confirm that mice were not immobilized by DBS. Recordings were performed without an investigator present. All mice were video-monitored during access to the high-fat diet on one day with DBS-on in half of the implanted cohort and DBS-off in the second half. Recordings were initiated at the start of the $1 \mathrm{~h}$ period. An investigator blinded to treatment groups measured both the latency to initiate locomotion once access to the high-fat pellet was provided and the latency to begin consuming this high-fat pellet.

Verification of electrode placement and c-Fos immunohistochemistry. Immediately after $1 \mathrm{~h}$ of DBS, mice were killed by trans-cardial perfusion. DBS was administered to half of the implanted mice at 12:00 P.M. A high-fat pellet was not provided on the day of perfusion to avoid the confound of binge eating on c-Fos-IR. Mice were anesthetized with 5\% isoflurane and perfused trans-cardially with heparinized normal saline $(0.9 \% \mathrm{NaCl} / 10 \mathrm{U}$ heparin/ml), then with ice-cold $4 \%$ paraformaldehyde fixative in $0.1 \mathrm{~m}$ PBS. Electrodes then were removed. Whole brains were extracted from the crania, postfixed for $24 \mathrm{~h}$, and submerged in $20 \%$ sucrose in $0.1 \mathrm{M}$ PBS for $\sim 48 \mathrm{~h}$. Brains were frozen and cut by microtome into $30 \mu \mathrm{m}$ coronal sections, which then were stored in cryoprotectant at -20 C (Watson et al., 1986).

To assay neuronal activation in response to DBS, immunohistochemistry for c-Fos was performed on free-floating sections as previously described (Goel et al., 2011). Brain sections were anatomically matched across all mice by an investigator blinded to treatment groups. Brain regions were identified using the Paxinos and Franklin mouse atlas (Paxinos and Watson, 1986). c-Fos-IR was quantified by counting labeled cells and taking the average across two regions of interest defined by a rectangular field at $20 \times$. These analyzed areas were of identical size and shape 
for each mouse. The approximate rostral-caudal levels relative to bregma of the analyzed regions were as follows: NAS $(+1.94 \mathrm{~mm}$ and $+1.34 \mathrm{~mm}$ ), and infralimbic cortex (ILC; $+1.94 \mathrm{~mm}$ and $+1.34 \mathrm{~mm}$ ). The number of c-Fos-IR cells was counted and averaged across sections containing relevant brain areas. A threshold was set to delineate c-Fos-IR from background, and only cells above threshold were included (IPLab, Biovision Technologies).

Pharmacologic blockade of DBS. In a separate cohort of mice, the effect of D1R or D2R antagonism during DBS was assessed $(N=9)$. Mice were provided limited access to the high-fat diet as described above. Mean high-fat intake across 3 consecutive days of stable consumption was calculated. DBS was then administered, and mice were assigned to three separate drug groups matched for their mean decrease in high-fat intake with DBS. After a day with DBS-off, mice were pretreated with a dopamine receptor antagonist or vehicle based on their assigned group. Specifically, vehicle (sterile saline $0.9 \%)$, a D1R antagonist $(0.075 \mathrm{mg} / \mathrm{kg}$ SCH-23390; Sigma-Aldrich) or a D2R antagonist (3 mg/kg raclopride; Sigma-Aldrich) was administered intraperitoneally $30 \mathrm{~min}$ before initiating DBS. On a subsequent day, antagonists were administered in the absence of DBS to examine the effect of dopamine receptor blockade on binge eating. All comparisons of the effects of these treatments on DBS or binge eating were made in reference to the mean decrease in high-fat intake with DBS alone defined as the control or mean caloric intake from high-fat, respectively. SCH-23390 and raclopride doses were selected based on previous studies (Shaham and Stewart, 1996; Fienberg et al., 1998; Luo et al., 2011).

Quantitative RT-PCR-based TaqMan. To determine the effect of binge eating on D1R and D2R gene expression within the NAS, brains were removed from a new cohort of nonsurgical mice $(N=7)$ after caloric intake from high-fat stabilized in the limited access protocol. Mice were killed at the time when access to this diet was routinely initiated (12:00 P.M.). Brains were immediately frozen on dry ice and stored at -80 C. A group of age- and weight-matched controls never exposed to the high-fat diet were included for comparison $(N=7)$. Brains were cut on a cryostat at $30 \mu \mathrm{m}$ and mounted on slides (SuperFrost Plus, Fisher Scientific). Brain punches $(0.75 \mathrm{~mm})$ of the NAS were obtained by micropunch (Harris Micro-Punch, Ted Pella) and placed into $500 \mu \mathrm{l}$ Trizol (Invitrogen), frozen on dry ice, and stored at $-80 \mathrm{C}$. RNA isolation was performed as previously described (Morgan and Bale, 2011). Approximately $250 \mathrm{ng}$ of total RNA from brain punches was reverse transcribed to cDNA using the High-Capacity cDNA reverse transcriptase kit (Applied Biosystems). qRT-PCR was performed using TaqMan probes (D1R, ID Mm02620146_s1; D2R, ID Mm00438545_m1) arranged onto a 96-well array (Dunn and Bale, 2011; Morgan and Bale, 2011). GAPDH was used as an endogenous loading control. Samples were run in triplicate, and expression levels of each sample were normalized to the average expression level in controls. Analysis was performed using the comparative $\mathrm{C}_{\mathrm{t}}$ method.

Diet-induced obesity. All mice $(N=8)$ were maintained on the high-fat diet for 16-20 weeks. During this time, mice were provided unrestricted, extended access to preweighed pellets in their home cage. No house chow was provided in this study to the surgical mice, but water was provided ad libitum. Consumption of the high-fat diet and body weights of obese mice were measured daily and compared with lean mice, which were maintained on house chow and never exposed to the high-fat diet $(N=4)$.

Chronic DBS. After recovery from surgery, obese mice were grouped into four weight-matched pairs, in which one mouse was with DBS-on and the other DBS-off. Mice were connected to external wires and monitored daily until high-fat intake (defined as $<15 \%$ variation in consumption over 3 consecutive days) and body weight stabilized (defined as $<2 \%$ variation in body weight over 3 consecutive days). NAS DBS was then administered continuously for $4 \mathrm{~d}$. The same stimulatory parameters with a current output of $150 \mu \mathrm{A}$ were used as described above. After $4 \mathrm{~d}$ of DBS, mice were disconnected from external wires and allowed to recover for 1 week. Mice were then reconnected and monitored daily until high-fat intake and body weight stabilized. A crossover design for DBS administration was then used. Mice were killed by trans-cardial perfusion, and electrode location was verified. One obese mouse was excluded from this analysis because of malfunction of its electrode.

Glucose tolerance test (GTT). Weight-matched obese and lean mice on house chow were fasted overnight for $12 \mathrm{~h}$. A $40 \%$ sterile glucose solution was freshly prepared. Beginning at $0800 \mathrm{~h}$, baseline glucose levels from tail snips were analyzed using the OneTouch Ultra (Johnson \& Johnson). Animals were then given an intraperitoneal injection of glucose $(2 \mathrm{mg} / \mathrm{g}$ body weight). Blood glucose measurements were obtained at 15, 30, 60, and $120 \mathrm{~min}$ after the injection. GTT (Dunn and Bale, 2011) was performed before initiating DBS to confirm that obese mice had impaired glucose tolerance compared with lean mice on house chow. GTT was repeated after the second half of the crossover design such that glucose tolerance was measured in half of the cohort with DBS-on and half with DBS-off.

Statistics. An investigator blind to animal treatment groups conducted all analyses and verification of electrode placement. Parametric analyses were used to analyze food intake, body weight, GTT, c-Fos-IR, gene expression, and the effects of dopamine receptor subtype antagonism on DBS and binge eating. Latency data were analyzed using nonparametric tests. All significant differences were defined as $p<0.05$. Statistical comparisons were performed using SPSS software (IBM SPSS Statistics).

\section{Results}

\section{Verification of electrode placement}

None of the ends of the electrode tracts intended for the NA were found outside of this nucleus. However, in the first experiment, eight of the 10 electrodes were localized to the NAS, whereas only two electrodes were in the accumbens core subregion (Fig. $1 B-$ $D$ ). Given possible differential roles of the shell and core in binge eating, we analyzed these mice separately (Bossert et al., 2007). Two mice were excluded because of excessive tissue damage during processing for immunohistochemistry. All electrodes implanted in the dorsal striatum were confirmed to be localized within this region (Fig. 1E).

\section{NAS DBS attenuates binge eating}

Our initial studies examined the effect of varying the current intensity of NAS DBS during limited access to the high-fat diet. A repeated-measures ANOVA was used with a group (DBS, nonsurgical controls) $\times$ current intensity $(75 \mu \mathrm{A}, 150 \mu \mathrm{A})$ design (Fig. $2 A)$. There was a main effect for group $\left(F_{(1,17)}=12.37 ; p<0.003\right)$, a main effect for current intensity $\left(F_{(1,17)}=21.20 ; p<0.0003\right)$, as well as an interaction effect between group and current intensity $\left(F_{(1,17)}=\right.$ $12.12 ; p<0.003)$. Subsequent between-group comparisons revealed a significant decrease in kilocalories consumed from high-fat with NAS DBS at $150 \mu \mathrm{A}\left(t_{(17)}=4.74 ; p<0.0001\right)$ but not at $75 \mu \mathrm{A}$ $\left(t_{(17)}=1.10\right.$; not significant). Thus, for all subsequent studies, a current intensity of $150 \mu \mathrm{A}$ was used.

In this limited access protocol, mice exposed to high-fat food exhibited an incremental increase in consumption of this diet until caloric intake from high-fat stabilized, and met our criteria for binge eating. This was specific to the palatable high-fat food, as when mice were provided a pellet of standard chow during this $1 \mathrm{~h}$ period, negligible amounts were consumed (Fig. 2B). Thus, before initiating DBS, criteria for stabilized binge eating of the high-fat diet were reached during the $3 \mathrm{~d}$ before administering DBS (Figs. 2C,D). To detect a difference in intake of the high-fat diet induced by NAS DBS $(150 \mu \mathrm{A})$, which was administered on 2 alternate days, a repeated-measures ANOVA was used with a group (DBS, nonsurgical controls) $\times$ day (days $0-3)$ design. There was a main effect for group $\left(F_{(1,13)}=5.88 ; p<0.03\right)$, an interaction effect between group and day $\left(F_{(3,39)}=10.01 ; p<\right.$ $0.0001)$, and a main effect for day $\left(F_{(3,39)}=8.14 ; p<0.0001\right)$. Subsequent between group comparisons revealed a significant decrease in kilocalories consumed on days $0\left(t_{(13)}=3.80 ; p<\right.$ 
A
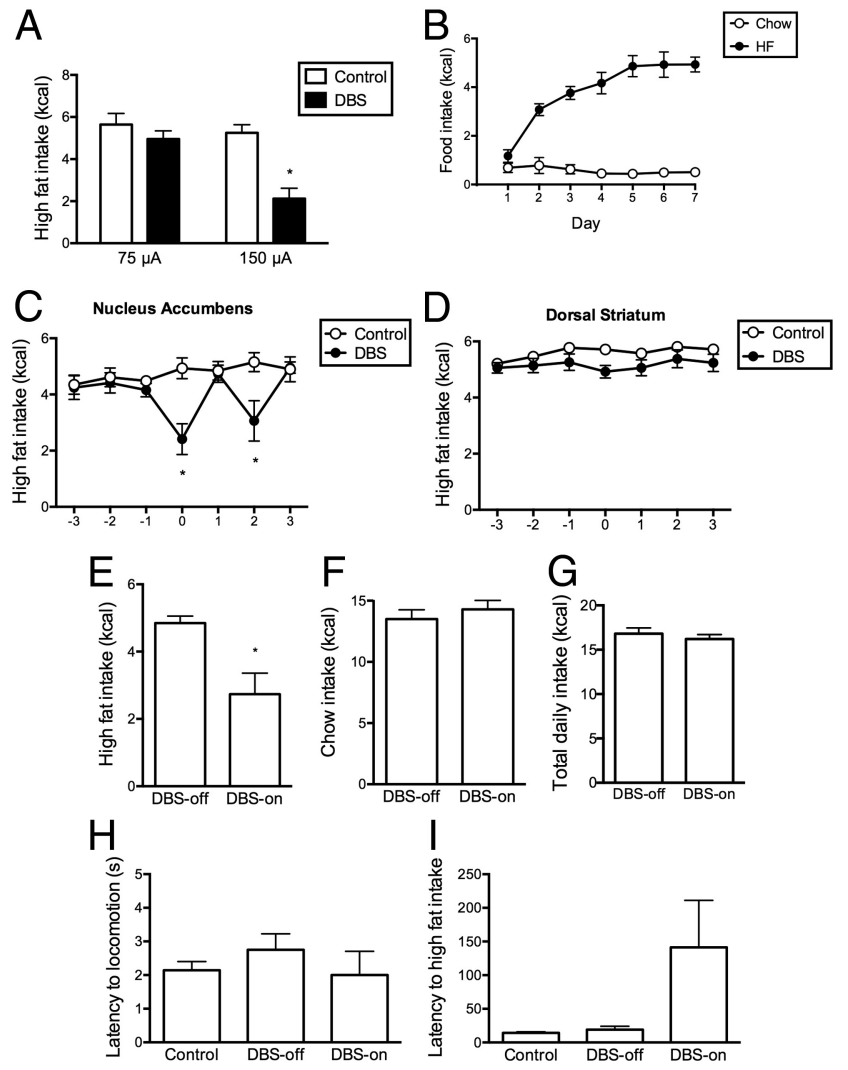

Figure 2. NAS DBS attenuates binge eating. $\boldsymbol{A}$, Initial studies revealed that NAS DBS ( $N=$ 11) significantly attenuated mean daily high-fat intake at $150 \mu \mathrm{A}$ but not at $75 \mu \mathrm{A}$ compared with nonsurgical controls $(N=9)$. $B$, Mice exposed to the high-fat diet exhibited an incremental increase in consumption until reaching stable levels $(N=7)$. Intake of a standard chow pellet in this same binge paradigm was negligible $(N=7)$. $C$, Once caloric intake from the high-fat diet stabilized for $3 \mathrm{~d}$ before starting DBS, NAS DBS $(150 \mu \mathrm{A})$ was administered on two alternate days $(N=8)$ and significantly decreased binge eating compared with nonsurgical controls $(N=7)$. $D$, DBS administered to the dorsal striatum $(N=7)$ had no impact on high-fat intake compared with controls $(N=8)$. $\boldsymbol{E}$, Within-group comparisons revealed a significant decrease in mean daily intake of high-fat food with NAS DBS-on compared with DBS-off. $\boldsymbol{F}$, Twenty-four-hour caloric intake from house chow decreased as binge eating developed, but this intake of chow did not return to baseline when caloric intake from high fat was suppressed by DBS. $\boldsymbol{G}$, NAS DBS did not alter total caloric intake. $\boldsymbol{H}$, Analysis of video recordings did not reveal a DBS-mediated difference in latency to locomotion once access to the high-fat diet was provided compared with mice with DBS-off. I, Although DBS appeared to increase latency to consume high-fat food, any apparent difference was not statistically significant. Data are mean per group \pm SEM. ${ }^{*} p<0.05$.

$0.002)$ and day $2\left(t_{(13)}=2.59 ; p<0.02\right)$ with DBS turned on (Fig. $2 C)$. These differences were not apparent in the two mice undergoing DBS of the accumbens core compared with controls with a lack of a main effect for group $\left(F_{(1,7)}=0.002\right.$; not significant), day $\left(F_{(3,21)}=1.20\right.$; not significant $)$, or an interaction effect between group and day $\left(F_{(3,21)}=0.77\right.$; not significant). In addition, DBS administered to the dorsal striatum did not appear to impact binge eating with a lack of main effect for group $\left(F_{(1,17)}=2.82\right.$; not significant), day $\left(F_{(3,51)}=1.14\right.$; not significant $)$, or an interaction effect between group and day $\left(F_{(3,51)}=0.40\right.$; not significant) (Fig. 2D).

Within-subject comparisons using paired $t$ tests of NAS DBS-on and DBS-off revealed a significant decrease in mean kilocalories consumed from the high-fat food $\left(t_{(7)}=3.08 ; p<0.02\right.$; Fig. 2E). Although DBS was turned off after the $1 \mathrm{~h}$ access period, comparisons of $24 \mathrm{~h}$ caloric intake from house chow were also made. As expected, caloric intake from chow significantly de- creased as binge eating of the high-fat food developed $\left(t_{(7)}=3.58\right.$; $p<0.006)$. Despite amelioration of binge eating with NAS DBS, there was no change in caloric intake from chow on those days $\left(t_{(7)}=1.74\right.$; not significant; Fig. $\left.2 F\right)$. There was also no difference in total daily kilocalories consumed (high-fat and house chow combined) $\left(t_{(7)}=1.49\right.$; not significant; Fig. $\left.2 G\right)$. A repeatedmeasures ANOVA was used to analyze body weight as a factor of binge eating and NAS DBS. A main effect for body weight was found after 1 week of binge eating $\left(F_{(2,26)}=8.35\right.$; $\left.p<0.002\right)$, but there was no interaction detected between body weight and NAS DBS.

\section{Video monitoring of activity}

A Kruskal-Wallis ANOVA by ranks was used to examine the latency to initiate locomotion in 3 groups (nonsurgical controls, NAS DBS-off, NAS DBS-on). No significant difference between these groups was found $\left(\chi_{(2)}^{2}=1.65\right.$; not significant; Fig. $\left.2 H\right)$. A Kruskal-Wallis ANOVA was again used to examine the latency to initiate consumption of the high-fat diet. Again, there was no significant difference between these groups $\left(\chi_{(2)}^{2}=4.01\right.$; not significant; Fig. $2 I$ ). No abnormal behaviors, including freezing, body turning, or pivoting, were observed in mice undergoing NAS DBS.

\section{Effects of DBS on c-Fos-IR in the NAS and ILC}

To investigate the effects of NAS DBS on neuronal activation both in the NAS and ILC (Fig. 3A), the number of c-Fos-IR cells in these regions was analyzed from brain tissue taken from mice $1 \mathrm{~h}$ after onset of DBS. This time point was selected to detect an effect on neuronal activation during the same time frame that DBS was administered for binge eating. Multivariate ANOVA with a group $($ DBS-off, DBS-on) $\times$ laterality design with respect to the DBS electrode (ipsilateral, contralateral) was performed to analyze c-Fos-IR in the NAS and ILC. Increased c-Fos-IR was found in the NAS ipsilateral $\left(F_{(1,6)}=6.66 ; p<0.04\right)$ and contralateral $\left(F_{(1,6)}=2.73\right.$; not significant $)$ to the DBS electrode, although this difference was only significant ipsilaterally (Fig. $3 B, C)$. There was no increase in c-Fos-IR in the ILC ipsilateral $\left(F_{(1,6)}=0.11\right.$; not significant $)$ or contralateral $\left(F_{(1,6)}=0.89\right.$; not significant) to the electrode.

\section{Pharmacological blockade of DBS}

To examine the effect of D1R and D2R antagonism on DBS, a separate group of mice implanted in the NAS with electrodes was exposed to the limited access protocol. Criteria for stabilized binge eating were reached, as previously described, and DBS was administered. The effect of DBS alone on binge eating was defined as the control for this study, to which we would compare high-fat intake when mice were pretreated with vehicle, SCH23390, or raclopride. A repeated-measures ANOVA with a between-subject factor (no DBS, DBS, DBS $\times$ vehicle, DBS $\times$ SCH-23390, DBS $\times$ raclopride, vehicle, $\mathrm{SCH}-23390$, raclopride) was performed to examine the mean intake of the high-fat diet during these various treatment conditions. There was significant attenuation of binge eating with $\operatorname{DBS}\left(F_{(1,6)}=150.15 ; p<0.0001\right.$; Fig. $4 A)$. DBS amelioration of binge eating was not altered by pretreating with $\mathrm{SCH}-23390\left(F_{(1,6)}=1.43\right.$; not significant $)$; however, raclopride significantly blunted the effect of DBS $\left(F_{(1,6)}=\right.$ $12.02 ; p<0.002$; Fig. $4 B)$. When antagonists were administered alone without DBS, there was no apparent effect on binge eating by SCH-23390 $\left(F_{(1,6)}=0.03\right.$; not significant $)$ or raclopride $\left(F_{(1,6)}\right.$ = 2.60; not significant) (Fig. $4 C$ ). 
Dopamine receptor expression after short-term limited access to a high-fat diet

To determine whether short-term limited access to a high-fat diet altered D1R or D2R expression levels, gene expression was examined in a subgroup of nonsurgical mice. There were no significant differences between binge eating mice and controls in expression of the D1R $\left(t_{(12)}=\right.$ 1.18; not significant) or D2R $\left(t_{(12)}=1.29\right.$; not significant) (Fig. 4D).

\section{Chronic NAS DBS in obesity}

After chronic access to the high-fat diet, diet-induced, obese mice exhibited both significant increases $(50.23 \pm 0.65 \mathrm{~g})$ in body weight $\left(t_{(10}=17.96 ; p<0.0001\right)$ compared with lean mice on chow $(31.33 \pm 0.60 \mathrm{~g})$ and impaired glucose clearance $\left(F_{(1,45)}=28.58\right.$; $p<0.0001)$. Criteria for stabilized consumption of the high-fat diet and body weight were reached $3 \mathrm{~d}$ before administering DBS. To detect a difference in intake of the high-fat diet induced by $4 \mathrm{~d}$ of continuously administered NAS DBS, a repeated-measures ANOVA was used with a group (DBS-off, DBS-on) $\times$ day (days $-1,0,1,2,3)$ design (Fig. 5A). There was a significant main effect for group $\left(F_{(1,6)}=6.90 ; p<0.04\right)$, an interaction effect between group and day $\left(F_{(4,24)}=3.79 ; p<0.02\right)$, but no main effect for day $\left(F_{(4,24)}=1.50\right.$; not significant). Between-group comparisons of mice receiving DBS to those with no DBS revealed a significant decrease in kilocalories consumed on the first day of DBS (day 0: $t_{(12)}=4.25 ; p<0.001$ ). No differences were detected on the subsequent $3 \mathrm{~d}$ of DBS. An analysis of total intake on days when DBS was administered revealed a significant decrease in total kilocalories consumed compared with days without DBS $\left(t_{(12)}=2.65 ; p<0.02\right)$ (Fig. $\left.5 B\right)$. After this 4 day administration of continuous NAS DBS, a significant decrease from baseline body weight was detected $\left(t_{(12)}=2.48\right.$; $p<0.03$ ) (Fig. 5C). However, an analysis of the impact of DBS on daily weight measurements revealed no significant differences (Fig. 5D).

\section{Chronic NAS DBS improves glucose tolerance}

To examine a difference in glucose tolerance after chronic NAS DBS, a repeated-measures ANOVA was used with a group (chow, obese DBS-off, obese DBS-on $) \times$ time $(0,15,30,60,120 \mathrm{~min})$ design. There was a main effect for group $\left(F_{(2,8)}=4.66 ; p<0.04\right)$, a main effect for time $\left(F_{(4,32)}=53.11 ; p<0.0001\right)$, but no interaction effect $\left(F_{(8,32)}=1.92\right.$; not significant $)$. All obese mice were found to have impaired glucose tolerance, according to subsequent between group comparisons (Fig. 5E): Mice with DBS turned off were different from lean mice on chow at $0(p<0.01)$, 30 ( $p<0.002), 60(p<0.002)$, and $120 \mathrm{~min}(p<0.04)$; mice with DBS turned on were different from chow at $0(p<0.003), 30$ $(p<0.03)$, and $120 \mathrm{~min}(p<0.03)$. According to an area under the curve (AUC) analysis, there was a main effect for group using a univariate ANOVA $\left(F_{(2,8)}=4.39 ; p<0.05\right.$; Fig. $\left.5 F\right)$. This difference was primarily the result of increased AUC in mice with DBS-off compared with lean mice $\left(t_{(5)}=4.89\right.$; $\left.p<0.004\right)$, as there was no difference between mice, which received DBS, and lean mice $\left(t_{(6)}=1.98\right.$; not significant).

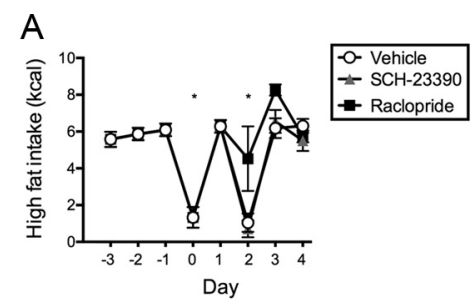

$B$
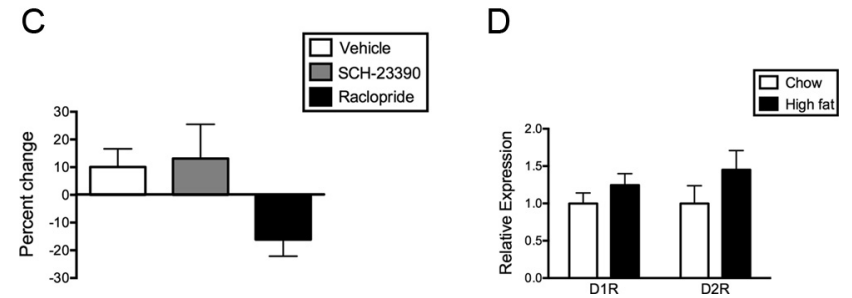

Figure 4. Pretreatment with raclopride attenuates the action of NASDBS on binge eating. $\boldsymbol{A}$ After $3 \mathrm{~d}$ of stable caloric intake from the high-fat diet, NAS DBS was administered to all mice and significantly decreased binge eating $(N=9)$. Only pretreatment with raclopride significantly blunted this effect of DBS. $\boldsymbol{B}$, Percentage change from daily mean caloric intake from high-fat resulting from DBS (control) was significantly decreased in mice pretreated with raclopride $(N=3)$, but not $\mathrm{SCH}-23390(N=3)$ or vehicle $(N=3)$. C, Neither raclopride nor SCH-23390 affected binge eating in the absence of DBS. $D$, There was no significant difference in relative $\operatorname{D1R}(N=7)$ or D2R $(N=7)$ expression in the NAS after short-term limited access to the high-fat diet. Mean per group \pm SEM. ${ }^{*} p<0.05$.

\section{Discussion}

The growing prevalence of obesity worldwide and its associated medical comorbidities, including impaired quality of life and decreased life expectancy, demand the development of novel treatments (Fontaine et al., 2003). Addressing the hedonic mechanisms of overconsumption in obesity by performing NAS DBS may provide therapeutic relief to certain individuals who are refractory to current approaches (Jeffery et al., 2004; Li et al., 2005; Gracia-Solanas et al., 2011). The NA is critical in mediating reward-seeking behaviors, including binge eating (Avena et al., 2008). DBS of this brain region, in particular the NAS, has been shown to attenuate cocaine priming-induced reinstatement, morphine reinforcement, and alcohol intake (Liu et al., 2008; Vassoler et al., 2008; Knapp et al., 2009; Henderson et al., 2010). Amelioration of binge eating with NAS DBS would support common neural circuitry underlying addiction and obesity, and may have broad translational potential (Nestler, 2004, 2005; Halpern et al., 2008; Halpern et al., 2011). 
A
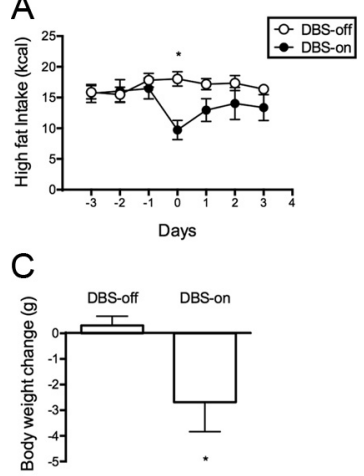

E

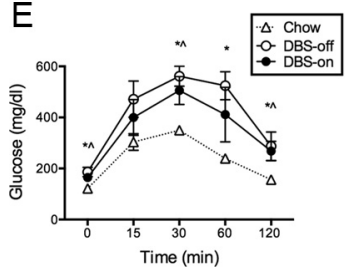

$B$
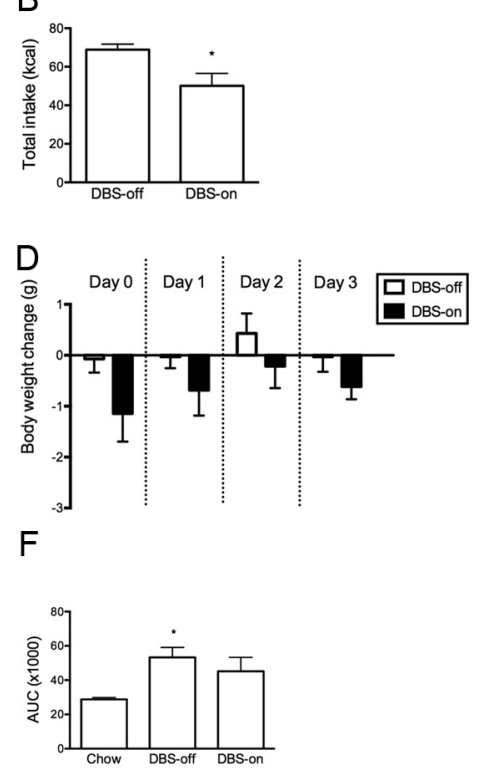

Figure 5. Chronic NAS DBS suppresses intake of high-fat food and body weight in dietinduced obese mice. $A$, After $3 \mathrm{~d}$ of diet intake stabilization, chronic NAS DBS was administered for $4 \mathrm{~d}(N=4)$ starting on day 0 . DBS decreased daily intake compared with obese mice without $\operatorname{DBS}(N=4) . B$, NAS DBS significantly decreased total caloric intake of the high-fat diet. $C$, There was a significant decrease in body weight after $4 \mathrm{~d}$ of chronic NAS DBS. $\boldsymbol{D}$, This difference appeared largely the result of the initial weight loss with DBS on day $0 . E$, Obese mice exhibited impaired glucose tolerance compared with lean mice. $\boldsymbol{F}$, An area under the curve analysis revealed that obese mice without DBS were significantly different from lean mice. Data are mean per group \pm SEM. ${ }^{*} p<0.05$, significant differences between obese mice without DBS and lean mice. $\hat{p}<0.05$, significant differences between obese mice with DBS and lean mice.

We used a limited access model of binge eating in which mice were allowed $1 \mathrm{~h}$ to consume a highly palatable and calorically dense high-fat diet (60\% fat) (Teegarden and Bale, 2008; Pankevich et al., 2010). As we hypothesized, NAS DBS at $150 \mu \mathrm{A}$, administered only during the $1 \mathrm{~h}$ access, significantly blunted high-fat consumption. DBS was administered on alternating days to assess potential lingering effects when the stimulator was turned off; however, binge eating returned to baseline, prestimulation levels in the absence of DBS. In addition, on days when DBS attenuated binge eating, total caloric intake from house chow was unchanged, suggesting that mice did not compensate for the loss of calories after DBS exposure. The effect of NAS DBS on this behavior was anatomically specific, as targeting the dorsal striatum had no influence on binge eating. DBS did not appear to impair locomotor activity, as the latency for the mice to move after placement of the high-fat pellet in the cage did not differ between treatment groups. Of note, the latency to initiate consumption of high-fat did increase with DBS as expected, although this measure did not reach significance, probably because of the high variability.

In our examination of neuronal activation in association with unilateral NAS DBS, c-Fos-IR was increased bilaterally, although the effect was only significant ipsilateral to DBS. c-Fos-IR was measured in the NAS and ILC (an aspect of the medial prefrontal cortex) as these two structures have a well-described functional relationship and role in food-seeking behavior (Sesack et al., 1989; Mitchell and Gratton, 1992; Wolf et al., 2009; Bossert et al., 2012; Cifani et al., 2012). The effects on neuronal activation in the NAS in this study echo previous reports of interhemispheric communication between limbic structures (Carr and Sesack,

2000; Yano et al., 2006). For example, unilateral blockade of dopamine receptors within the striatum has altered methylphenidate-induced gene expression in the NA contralaterally (Yano et al., 2006). Clinically, unilateral DBS of the NA has provided relief to patients with obsessive-compulsive disorder (Huff et al., 2010), and subthalamic nucleus DBS increases contralateral brain activity in movement disorder patients (Walker et al., 2009; Walker et al., 2011). Bilateral neuronal activation in response to unilateral DBS provides further support for these preclinical and clinical findings and suggests that output from the NAS can modulate the contralateral NAS via crossed connections. A unilateral procedure would be important to consider for human translation resulting from the reduced morbidity risk compared with bilateral DBS (Alberts et al., 2008).

To determine dopamine receptor involvement in the effects of NAS DBS on inhibition of binge eating, blockade of D1Rs and D2Rs was carried out by administration of receptor-specific antagonists before DBS onset. D2R, but not D1R, antagonism significantly blunted the effect of NAS DBS, supporting an involvement for dopamine signaling at the D2R that mediates inhibition of binge eating by DBS. The anatomical specificity of this effect remains unclear, however, as the antagonists were administered peripherally. Increased dopamine release in the NAS has been previously associated with regulation of intake of highly palatable foods and chronically may lead to the reported downregulation of the D2R in obesity (Wise and Rompre, 1989; Johnson and Kenny, 2010; Stice et al., 2011). Accordingly, it is tempting to speculate that the effect of the antagonist may involve actions in the NAS. In contrast to the growing literature on dopamine release in the NAS, much less is known about the effect of relatively short-term exposure of a highly palatable diet on D2R expression. Therefore, we examined gene expression levels of D1Rs and D2Rs within the NAS after short-term access to the high-fat food. There were no significant changes in expression of either receptor, suggesting that the effects of the D2 antagonist on DBS were likely not a function of differences in receptor levels. Together, DBS in the NAS may lead to local release of dopamine, which in turn is binding to D2Rs, and blocking some of the hedonic valence of this high-fat diet (Sesia et al., 2010). Given neuronal activation using c-Fos-IR as a surrogate marker was seen in the NAS, the finding that D2R antagonism inhibited the action of DBS on binge eating may seem paradoxical. The D2R is known to signal through distinct $\mathrm{G}_{\mathrm{i}} \alpha$ proteins to inhibit adenylyl cyclase (Senogles, 1994). This paradox may speak to the nonspecificity of c-Fos-IR given that the expression of the D2R has been reported not only on medium spiny neurons, but also on cholinergic neurons in the NA (Le Moine et al., 1990). However, inhibition of neurons expressing the D2R may lead to disinhibition of intraaccumbens projections, which would be consistent with increased c-Fos-IR with DBS (van Dongen et al., 2005).

Our results indicate that acute administration of NAS DBS may provide a novel therapeutic approach for certain obese human subjects with binge eating. Acute effects of DBS have been reported in humans, including intraoperative tremor suppression in Parkinson's and mood changes in psychiatric patients (Haq et al., 2011). These acute effects greatly impact localizations of the neural target for electrode implantation in humans (Kramer et al., 2010). In addition, as more real-time, adaptive (closed-loop), neuromodulatory devices are developed that are capable of delivering current in response to neural oscillatory activity (Rosin et al., 2011), animal studies will need to continue to examine the acute effects of DBS on aberrant behaviors associated with obesity and other diseases. Moreover, NAS DBS does 
appear to attenuate caloric intake and induce body weight loss in mice in the obese state. However, the duration and magnitude of these effects suggest a more robust, acute response to chronic DBS. Effects on glucose tolerance were not robust likely because of the limited $4 \mathrm{~d}$ DBS examination.

Although these studies demonstrate robust effects of NAS DBS on the hedonic aspects of feeding behavior, there are noted limitations related to the lack of mechanistic specificity with this methodology, as it is not clear which cells are being modulated by DBS. Whereas $90 \%$ of the neurons in the accumbens are medium spiny neurons modulated by dopamine, other cell types include GABAergic interneurons and cholinergic neurons (Wilson, 1993). The importance of anatomic specificity can also not be overlooked. The present studies provide substantial evidence for anatomical specificity of NAS DBS, given that DBS of the dorsal striatum did not influence binge eating, and two mice implanted in the NA core were not responsive to DBS. Our model precluded examining the effects of DBS on consumption of standard chow in this binge paradigm as mice consumed negligible amounts of the chow during the $1 \mathrm{~h}$ limited access period. Last, the potential lack of effect of the D1R antagonist may have been the result of an unbalanced repeated measure design, in which the pharmacologic agents or DBS were administered on a single day, rather than balancing them across multiple days of testing. Future work applying optogenetic techniques will allow us to dissect this circuit to further our understanding of both the anatomic and cellular bases of the mechanisms underlying amelioration of binge eating with NAS DBS.

In conclusion, the current results indicate that binge eating was ameliorated by acute administration of unilateral NAS DBS, and this effect was mediated in part by activation of the D2R. Collectively, these findings further implicate the mesolimbic dopamine system in the overconsumption of calorically dense food, a behavior known to contribute to obesity. This study provides preclinical support for the potential utilization of DBS in controlling aberrant eating behaviors associated with obesity.

\section{References}

Agterberg MJ, Spoelstra EN, van der Wijst S, Brakkee JH, Wiegant VM, Hamelink R, Brouns K, Westerink BH, Remie R (2010) Evaluation of temperature rise and bonding strength in cements used for permanent head attachments in rats and mice. Lab Anim 44:264-270. CrossRef Medline

Alberts JL, Voelcker-Rehage C, Hallahan K, Vitek M, Bamzai R, Vitek JL (2008) Bilateral subthalamic stimulation impairs cognitive-motor performance in Parkinson's disease patients. Brain 131:3348-3360. CrossRef Medline

Avena NM, Bocarsly ME, Rada P, Kim A, Hoebel BG (2008) After daily bingeing on a sucrose solution, food deprivation induces anxiety and accumbens dopamine/acetylcholine imbalance. Physiol Behav 94:309315. CrossRef Medline

Benazzouz A, Hallett M (2000) Mechanism of action of deep brain stimulation. Neurology 55 [Suppl 6]:S13-S16. Medline

Bewernick BH, Kayser S, Sturm V, Schlaepfer TE (2012) Long-term effects of nucleus accumbens deep brain stimulation in treatment-resistant depression: evidence for sustained efficacy. Neuropsychopharmacology.37: 1975-1985 Medline

Bossert JM, Poles GC, Wihbey KA, Koya E, Shaham Y (2007) Differential effects of blockade of dopamine D1-family receptors in nucleus accumbens core or shell on reinstatement of heroin seeking induced by contextual and discrete cues. J Neurosci 27:12655-12663. CrossRef Medline

Bossert JM, Stern AL, Theberge FR, Marchant NJ, Wang HL, Morales M, Shaham Y (2012) Role of projections from ventral medial prefrontal cortex to nucleus accumbens shell in context-induced reinstatement of heroin seeking. J Neurosci 32:4982-4991. CrossRef Medline

Carr DB, Sesack SR (2000) Projections from the rat prefrontal cortex to the ventral tegmental area: target specificity in the synaptic associations with mesoaccumbens and mesocortical neurons. J Neurosci 20:3864-3873. Medline

Chang JY, Shi LH, Luo F, Woodward DJ (2003) High frequency stimulation of the subthalamic nucleus improves treadmill locomotion in unilateral 6-hydroxydopamine lesioned rats. Brain Res 983:174-184. CrossRef Medline

Cifani C, Koya E, Navarre BM, Calu DJ, Baumann MH, Marchant NJ, Liu QR, Khuc T, Pickel J, Lupica CR, Shaham Y, Hope BT (2012) Medial prefrontal cortex neuronal activation and synaptic alterations after stressinduced reinstatement of palatable food seeking: a study using c-fos-GFP transgenic female rats. J Neurosci 32:8480-8490. CrossRef Medline

Dunn GA, Bale TL (2011) Maternal high-fat diet effects on third-generation female body size via the paternal lineage. Endocrinology 152:2228-2236. CrossRef Medline

Fienberg AA, Hiroi N, Mermelstein PG, Song W, Snyder GL, Nishi A, Cheramy A, O'Callaghan JP, Miller DB, Cole DG, Corbett R, Haile CN, Cooper DC, Onn SP, Grace AA, Ouimet CC, White FJ, Hyman SE, Surmeier DJ, Girault J, et al. (1998) DARPP-32: regulator of the efficacy of dopaminergic neurotransmission. Science 281:838-842. CrossRef Medline

Finucane MM, Stevens GA, Cowan MJ, Danaei G, Lin JK, Paciorek CJ, Singh GM, Gutierrez HR, Lu Y, Bahalim AN, Farzadfar F, Riley LM, Ezzati M (2011) National, regional, and global trends in body-mass index since 1980: systematic analysis of health examination surveys and epidemiological studies with 960 country-years and 9.1 million participants. Lancet 377:557-567. CrossRef Medline

Fontaine KR, Redden DT, Wang C, Westfall AO, Allison DB (2003) Years of life lost due to obesity. JAMA 289:187-193. CrossRef Medline

Georgescu D, Sears RM, Hommel JD, Barrot M, Bolaños CA, Marsh DJ, Bednarek MA, Bibb JA, Maratos-Flier E, Nestler EJ, DiLeone RJ (2005) The hypothalamic neuropeptide melanin-concentrating hormone acts in the nucleus accumbens to modulate feeding behavior and forced-swim performance. J Neurosci 25:2933-2940. CrossRef Medline

Goel N, Plyler KS, Daniels D, Bale TL (2011) Androgenic influence on serotonergic activation of the HPA stress axis. Endocrinology 152:2001-2010. CrossRef Medline

Gorin AA, Niemeier HM, Hogan P, Coday M, Davis C, DiLillo VG, Gluck ME, Wadden TA, West DS, Williamson D, Yanovski SZ (2008) Binge eating and weight loss outcomes in overweight and obese individuals with type 2 diabetes: results from the Look AHEAD trial. Arch Gen Psychiatry 65:1447-1455. CrossRef Medline

Gracia-Solanas JA, Elia M, Aguilella V, Ramirez JM, Martínez J, Bielsa MA, Martínez M (2011) Metabolic syndrome after bariatric surgery: results depending on the technique performed. Obes Surg 21:179-185. CrossRef Medline

Halpern CH, Wolf JA, Bale TL, Stunkard AJ, Danish SF, Grossman M, Jaggi JL, Grady MS, Baltuch GH (2008) Deep brain stimulation in the treatment of obesity. J Neurosurg 109:625-634. CrossRef Medline

Halpern CH, Torres N, Hurtig HI, Wolf JA, Stephen J, Oh MY, Williams NN, Dichter MA, Jaggi JL, Caplan AL, Kampman KM, Wadden TA, Whiting DM, Baltuch GH (2011) Expanding applications of deep brain stimulation: a potential therapeutic role in obesity and addiction management. Acta Neurochir (Wien) 153:2293-2306. CrossRef Medline

Halpern C, Hurtig H, Jaggi J, Grossman M, Won M, Baltuch G (2007) Deep brain stimulation in neurologic disorders. Parkinsonism Relat Disord 13:1-16. CrossRef Medline

Haq IU, Foote KD, Goodman WG, Wu SS, Sudhyadhom A, Ricciuti N, Siddiqui MS, Bowers D, Jacobson CE, Ward H, Okun MS (2011) Smile and laughter induction and intraoperative predictors of response to deep brain stimulation for obsessive-compulsive disorder. Neuroimage 54 [Suppl 1]:S247-S255.

Henderson MB, Green AI, Bradford PS, Chau DT, Roberts DW, Leiter JC (2010) Deep brain stimulation of the nucleus accumbens reduces alcohol intake in alcohol-preferring rats. Neurosurg Focus 29:E12. CrossRef Medline

Hsu LK, Sullivan SP, Benotti PN (1997) Eating disturbances and outcome of gastric bypass surgery: a pilot study. Int J Eat Disord 21:385-390. CrossRef Medline

Huff W, Lenartz D, Schormann M, Lee SH, Kuhn J, Koulousakis A, Mai J, Daumann J, Maarouf M, Klosterkötter J, Sturm V (2010) Unilateral deep brain stimulation of the nucleus accumbens in patients with treatment-resistant obsessive-compulsive disorder: outcomes after one year. Clin Neurol Neurosurg 112:137-143. CrossRef Medline 
Jeffery RW, Kelly KM, Rothman AJ, Sherwood NE, Boutelle KN (2004) The weight loss experience: a descriptive analysis. Ann Behav Med 27:100106. CrossRef Medline

Johnson PM, Kenny PJ (2010) Dopamine D2 receptors in addiction-like reward dysfunction and compulsive eating in obese rats. Nat Neurosci 13:635-641. CrossRef Medline

Knapp CM, Tozier L, Pak A, Ciraulo DA, Kornetsky C (2009) Deep brain stimulation of the nucleus accumbens reduces ethanol consumption in rats. Pharmacol Biochem Behav 92:474-479. CrossRef Medline

Kramer DR, Halpern CH, Buonacore DL, McGill KR, Hurtig HI, Jaggi JL, Baltuch GH (2010) Best surgical practices: a stepwise approach to the University of Pennsylvania deep brain stimulation protocol. Neurosurg Focus 29:E3. CrossRef Medline

Lamont EW, Patterson Z, Rodrigues T, Vallejos O, Blum ID, Abizaid A (2012) Ghrelin-deficient mice have fewer orexin cells and reduced cFOS expression in the mesolimbic dopamine pathway under a restricted feeding paradigm. Neuroscience 218:12-19. CrossRef Medline

Le Moine C, Tison F, Bloch B (1990) D2 dopamine receptor gene expression by cholinergic neurons in the rat striatum. Neurosci Lett 117:248-252. CrossRef Medline

Li Z, Maglione M, Tu W, Mojica W, Arterburn D, Shugarman LR, Hilton L, Suttorp M, Solomon V, Shekelle PG, Morton SC (2005) Meta-analysis: pharmacologic treatment of obesity. Ann Intern Med 142:532-546. Medline

Liu HY, Jin J, Tang JS, Sun WX, Jia H, Yang XP, Cui JM, Wang CG (2008) Chronic deep brain stimulation in the rat nucleus accumbens and its effect on morphine reinforcement. Addict Biol 13:40-46. CrossRef Medline

Luo Z, Volkow ND, Heintz N, Pan Y, Du C (2011) Acute cocaine induces fast activation of $\mathrm{D} 1$ receptor and progressive deactivation of $\mathrm{D} 2$ receptor striatal neurons: in vivo optical microprobe $\left[\mathrm{Ca}^{2+}\right] i$ imaging. J Neurosci 31:13180-13190. CrossRef Medline

Mayberg HS, Lozano AM, Voon V, McNeely HE, Seminowicz D, Hamani C, Schwalb JM, Kennedy SH (2005) Deep brain stimulation for treatmentresistant depression. Neuron 45:651-660. CrossRef Medline

Mitchell JB, Gratton A (1992) Partial dopamine depletion of the prefrontal cortex leads to enhanced mesolimbic dopamine release elicited by repeated exposure to naturally reinforcing stimuli. J Neurosci 12:3609-3618. Medline

Morgan CP, Bale TL (2011) Early prenatal stress epigenetically programs dysmasculinization in second-generation offspring via the paternal lineage. J Neurosci 31:11748-11755. CrossRef Medline

Müller UJ, Sturm V, Voges J, Heinze HJ, Galazky I, Heldmann M, Scheich H, Bogerts B (2009) Successful treatment of chronic resistant alcoholism by deep brain stimulation of nucleus accumbens: first experience with three cases. Pharmacopsychiatry 42:288-291. CrossRef Medline

Nair SG, Adams-Deutsch T, Epstein DH, Shaham Y (2009) The neuropharmacology of relapse to food seeking: methodology, main findings, and comparison with relapse to drug seeking. Prog Neurobiol 89:18-45. CrossRef Medline

Nestler EJ (2004) Molecular mechanisms of drug addiction. Neuropharmacology 47 [Suppl 1]:24-32.

Nestler EJ (2005) Is there a common molecular pathway for addiction? Nat Neurosci 8:1445-1449. CrossRef Medline

Okun MS, Mann G, Foote KD, Shapira NA, Bowers D, Springer U, Knight W, Martin P, Goodman WK (2007) Deep brain stimulation in the internal capsule and nucleus accumbens region: responses observed during active and sham programming. J Neurol Neurosurg Psychiatry 78:310-314. CrossRef Medline

Pankevich DE, Teegarden SL, Hedin AD, Jensen CL, Bale TL (2010) Caloric restriction experience reprograms stress and orexigenic pathways and promotes binge eating. J Neurosci 30:16399-16407. CrossRef Medline

Paxinos G, Watson C (1986) The rat brain in stereotaxic coordinates, Ed 2. New York: Academic.

Rosin B, Slovik M, Mitelman R, Rivlin-Etzion M, Haber SN, Israel Z, Vaadia E, Bergman H (2011) Closed-loop deep brain stimulation is superior in ameliorating parkinsonism. Neuron 72:370-384. CrossRef Medline

Schlaepfer TE, Cohen MX, Frick C, Kosel M, Brodesser D, Axmacher N, Joe AY, Kreft M, Lenartz D, Sturm V (2008) Deep brain stimulation to reward circuitry alleviates anhedonia in refractory major depression. Neuropsychopharmacology 33:368-377. CrossRef Medline

Senogles SE (1994) The D2 dopamine receptor isoforms signal through dis- tinct Gi $\alpha$ proteins to inhibit adenylyl cyclase: a study with site-directed mutant Gi $\alpha$ proteins. J Biol Chem 269:23120-23127. Medline

Sesack SR, Deutch AY, Roth RH, Bunney BS (1989) Topographical organization of the efferent projections of the medial prefrontal cortex in the rat: an anterograde tract-tracing study with Phaseolus vulgaris leucoagglutinin. J Comp Neurol 290:213-242. CrossRef Medline

Sesia T, Bulthuis V, Tan S, Lim LW, Vlamings R, Blokland A, Steinbusch HW, Sharp T, Visser-Vandewalle V, Temel Y (2010) Deep brain stimulation of the nucleus accumbens shell increases impulsive behavior and tissue levels of dopamine and serotonin. Exp Neurol 225:302-309. CrossRef Medline

Shaham Y, Stewart J (1996) Effects of opioid and dopamine receptor antagonists on relapse induced by stress and re-exposure to heroin in rats. Psychopharmacology (Berl) 125:385-391. CrossRef Medline

Shi WX, Rayport S (1994) GABA synapses formed in vitro by local axon collaterals of nucleus accumbens neurons. J Neurosci 14:4548-4560. Medline

Stice E, Spoor S, Bohon C, Small DM (2008) Relation between obesity and blunted striatal response to food is moderated by TaqIA Al allele. Science 322:449-452. CrossRef Medline

Stice E, Yokum S, Burger KS, Epstein LH, Small DM (2011) Youth at risk for obesity show greater activation of striatal and somatosensory regions to food. J Neurosci 31:4360-4366. CrossRef Medline

Stoeckel LE, Weller RE, Cook EW 3rd, Twieg DB, Knowlton RC, Cox JE (2008) Widespread reward-system activation in obese women in response to pictures of high-calorie foods. Neuroimage 41:636-647. CrossRef Medline

Sturm R (2007) Increases in morbid obesity in the USA: 2000-2005. Public Health 121:492-496. CrossRef Medline

Tanda G, Di Chiara G (1998) A dopamine-mul opioid link in the rat ventral tegmentum shared by palatable food (Fonzies) and non-psychostimulant drugs of abuse. Eur J Neurosci 10:1179-1187. CrossRef Medline

Teegarden SL, Bale TL (2007) Decreases in dietary preference produce increased emotionality and risk for dietary relapse. Biol Psychiatry 61:10211029. CrossRef Medline

Teegarden SL, Bale TL (2008) Effects of stress on dietary preference and intake are dependent on access and stress sensitivity. Physiol Behav 93: 713-723. CrossRef Medline

Teegarden SL, Nestler EJ, Bale TL (2008) Delta FosB-mediated alterations in dopamine signaling are normalized by a palatable high-fat diet. Biol Psychiatry 64:941-950. CrossRef Medline

Toft M, Lilleeng B, Ramm-Pettersen J, Skogseid IM, Gundersen V, Gerdts R, Pedersen L, Skjelland M, Røste GK, Dietrichs E (2011) Long-term efficacy and mortality in Parkinson's disease patients treated with subthalamic stimulation. Mov Disord 26:1931-1934. CrossRef Medline

Valencia-Alfonso CE, Luigjes J, Smolders R, Cohen MX, Levar N, Mazaheri A, van den Munckhof P, Schuurman PR, van den Brink W, Denys D (2012) Effective deep brain stimulation in heroin addiction: a case report with complementary intracranial electroencephalogram. Biol Psychiatry 71: e35-e37. CrossRef Medline

van Dongen YC, Deniau JM, Pennartz CM, Galis-de Graaf Y, Voorn P, Thierry AM, Groenewegen HJ (2005) Anatomical evidence for direct connections between the shell and core subregions of the rat nucleus accumbens. Neuroscience 136:1049-1071. CrossRef Medline

Vassoler FM, Schmidt HD, Gerard ME, Famous KR, Ciraulo DA, Kornetsky C, Knapp CM, Pierce RC (2008) Deep brain stimulation of the nucleus accumbens shell attenuates cocaine priming-induced reinstatement of drug seeking in rats. J Neurosci 28:8735-8739. CrossRef Medline

Volkow ND, Wang GJ, Telang F, Fowler JS, Thanos PK, Logan J, Alexoff D, Ding YS, Wong C, Ma Y, Pradhan K (2008) Low dopamine striatal D2 receptors are associated with prefrontal metabolism in obese subjects: possible contributing factors. Neuroimage 42:1537-1543. CrossRef Medline

Walker HC, Watts RL, Guthrie S, Wang D, Guthrie BL (2009) Bilateral effects of unilateral subthalamic deep brain stimulation on Parkinson's disease at 1 year. Neurosurgery 65:302-309; discussion 309-310. CrossRef Medline

Walker HC, Watts RL, Schrandt CJ, Huang H, Guthrie SL, Guthrie BL, Montgomery EB Jr (2011) Activation of subthalamic neurons by contralateral subthalamic deep brain stimulation in Parkinson disease. J Neurophysiol 105:1112-1121. CrossRef Medline

Wang GJ, Volkow ND, Logan J, Pappas NR, Wong CT, Zhu W, Netusil N, 
Fowler JS (2001) Brain dopamine and obesity. Lancet 357:354-357. CrossRef Medline

Watson RE Jr, Wiegand SJ, Clough RW, Hoffman GE (1986) Use of cryoprotectant to maintain long-term peptide immunoreactivity and tissue morphology. Peptides 7:155-159. CrossRef Medline

Wilson CJ (1993) The generation of natural firing patterns in neostriatal neurons. Prog Brain Res 99:277-297. CrossRef Medline

Wise RA (2012) Dual roles of dopamine in food and drug seeking: the drivereward paradox. Biol Psychiatry Advance online publication. doi: 10.1016/j.biopsych.2012.09.001. Retrieved October 5, 2012. CrossRef Medline
Wise RA, Rompre PP (1989) Brain dopamine and reward. Annu Rev Psychol 40:191-225. CrossRef Medline

Wolf JA, Finkel LH, Contreras D (2009) Sublinear summation of afferent inputs to the nucleus accumbens in the awake rat. J Physiol 587:1695-1704. CrossRef Medline

Yano M, Beverley JA, Steiner H (2006) Inhibition of methylphenidateinduced gene expression in the striatum by local blockade of D1 dopamine receptors: interhemispheric effects. Neuroscience 140:699-709. CrossRef Medline 